\title{
Effect of Leech application in Prolapsed thrombosed hemorrhoid: A case study
}

\section{Case Report}

\section{Danish Javed $^{1^{*}}$}

1. Clinical Registrar (Shalya),

Ch. Brahm Prakash Ayurved Charak Sansthan, Khera Dabar, Najafgarh, New Delhi-110073.

\begin{abstract}
Prolapsed hemorrhoid is an emergency condition. The condition becomes worse after thrombosis and strangulation of the pile mass. Urgent surgical intervention is required in all the cases. Venous return of strangulated pile mass become very low and severe edema takes place along with serious painful condition. Hemorrhoidal mass is not able to reduce further in anal canal. Patient struck in serious woe and seeks urgent surgical attention. Leeches can be used as a successful tool in this situation by relieving venous pooling of blood and also by liquefying the clotted blood in pile mass. In present case study, a patient of grade IV hemorrhoid was cured by leech application.
\end{abstract}

Keywords: Leech therapy, Prolapsed hemorrhoid, jalaukavacharana, Arsha Chikitsa.

\section{Introduction}

Hemorrhoid or Arsha is considered as Mahagada in Ayurveda (1). It is a common disease of anal canal. Charak believes that vitiated doshas follow bahya and abhyantar rogamarga to produce Arsha (2). Sushuta has described Arsha as Rakta-Mansa pradoshaj Vyadhi (3). Bleeding and mass coming out per-anum are common complaints. Complication of Arsha include trishna (thirst), aruchi (anorexia), shoola (severe pain), shonit prasruti (excessive bleeding), shofa (odema), atisara (diarrhea) as per the Sushruta (4). In Ayurveda, kshar sutra ligation is a preferred surgical treatment in advance stage of Arsha. But, in some situation, where surgery is not possible, due to patient condition, "Leech Therapy" is a good alternative treatment available. However, Sushruta has contra-indicated bloodletting in Arsha (5). But in certain critical situation of hemorrhoids, it is advisable (6). Charak has mentioned Jalauka Karma in Raktasha (Bleeding pile mass) (7). Vagbhata has also advised bloodletting in sanchit dushta rudhira (Thombosed), shoon (swelling) and kathin (hard) Arsha (pile mass) (8). The present study is a case report of a grade IV Hemorrhoid patient, which was treated successfully with leech application.

\section{Aim}

The aim of this case study was to find out the results of Leech application in a case of prolapsed and thrombosed Hemorrhoids.

\section{Case report}

A female patient named Mewa Devi, W/o Sh.

*Corresponding Author:

\section{Danish Javed}

Clinical Registrar (Shalya),

Ch. Brahm Prakash Ayurved Charak Sansthan,

Khera Dabar, Najafgarh,

New Delhi-110073

E-mail: danish_surgeon@,rediffmail.com
Teki, age 60 years, r/o Bakner, Delhi, OPD registration no 87256 came in OPD no. 16 of shalya department in Ch. Brahm Prakash Ayurved Charak Sansthan, New Delhi on 23-08-2016 at 11.23 AM in a very panic and emergency like situation. Her face was in agony and she was seeking medical attention in urgent need. She had the following complains since 2 days:

- Severe pain and burning sensation in anal region

- Big mass coming out from anal verge

- Bleeding per rectum

- Difficulty in passing stool

- Constipation

She had not taken any medical advice and she directly came here for treatment.

\section{Past History:}

She had a past history of surgery of hemorrhoids at an allopathic hospital about seventeen years back. She had no history of diabetes, hypertension, coronary heart disease, cerebro-vascular accident or Koch's.

\section{Examination:}

Patient was examined in lithotomy position. She was having a severe necrotizing, foul smelling, black mass coming out from her anal verge. After proper examination, it was found that there was a large prolapsed, thrombosed pile mass at 11 O'clock, one prolapsed mass at 3 O'clock and one at 5 O'clock. It was tried to reduce the mass after applying jatyadi taila, but it could not be possible. So, it was diagnosed as a case of Grade IV Hemorrhoid. The patient was admitted in female surgical ward no. 6 , bed no. 156, IPD registration no. 5421 .

\section{Systemic Examination:}

Patient was conscious, well-oriented and with good general condition. Her vitals were recorded normal. Blood pressure was 120/80, pulse rate was 94 and temperature was $99^{\circ} \mathrm{F}$. 
Blood Investigations: (Dated: 26.08.2016) Lab no: 680

- $\mathrm{Hb}: 11.6 \mathrm{gm} / \mathrm{dl}$

- TLC: 4,600/cumm (N:77,L:19,M:02,E:02,B:0)

- $\mathrm{RBC}$ count 4.33 millions/cmm

- PCV/Hematocrit 34.6\%

- MCV 79.9fL

- $\mathrm{MCHC} 33.5 \mathrm{gm} / \mathrm{dl}$

- $\mathrm{MCH} 26.8$ picogram

- Platelet Count 1.91 Lakh/cmm

- Bleeding Time $01 \mathrm{~min} 50 \mathrm{sec}$

- Clotting Time $05 \mathrm{~min} 10 \mathrm{sec}$

- Blood Sugar Random 94 mg/dl

- Hepatitis B Surface Antigen (HbsAg) NonReactive

- HIV 1 (Antibodies) Non-Reactive

- HIV 2 (Antibodies) Non-Reactive

\section{Methodology:}

After proper investigation, leech therapy was planned as a first line treatment in this case. Patient was febrile on the day of admission. So, Jwarnashak Chikitsa was given with Sanjeevani vati and Sudarshan ghan vati for first two days along with the Ayurvedic management for Arsha. Fever was relieved on third day (Figure 1). On fourth day, leech therapy was advised.

After taking written consent of patient, she was kept in lithotomy position. Two leeches were applied at anal verge on each side of prolapsed mass on 27-082016. Consecutive second sitting of leech application was given on 29-08-2016 and third sitting on 01-092016. Patient was discharged on 03-09-2016 morning after complete recovery.

\section{Oral Medication:}

Arsh Kuthar Ras 2 tablets BD, Abhayarisha 4 tsf BD, Haritaki Churna 10 gm HS. Anupana was Luke warm water in sufficient quantity.

\section{Local application:}

Hot Sitz bath with Tankan Bhasm, Local application of paste (pralepa) of Madhuyasti churna with Jatyadi oil.

\section{Observation}

Symptoms were taken into consideration under grading system according to their severity.

- No symptom $=0$

- Mild = 1

- Moderate $=2$

- Severe $=3$

Observation was done after every sitting of leech application and tabulated as below in Table 1 .
Table 1

\begin{tabular}{|c|c|c|c|c|}
\hline Variables & BT & $\begin{array}{c}1^{\text {st }} \\
\text { Sitting }\end{array}$ & $\begin{array}{c}2^{\text {nd }} \\
\text { Sitting }\end{array}$ & $\begin{array}{c}3^{\text {rd }} \\
\text { Sitting }\end{array}$ \\
\hline Pain & 3 & 3 & 2 & 0 \\
\hline Tenderness & 2 & 1 & 0 & 0 \\
\hline $\begin{array}{c}\text { Burning } \\
\text { Sensation }\end{array}$ & 3 & 2 & 0 & 0 \\
\hline Bleeding & 3 & 2 & 1 & 0 \\
\hline $\begin{array}{c}\text { Mucous } \\
\text { Discharge }\end{array}$ & 2 & 1 & 1 & 0 \\
\hline $\begin{array}{c}\text { Mass } \\
\text { Prolapsed }\end{array}$ & 3 & 3 & 2 & 1 \\
\hline $\begin{array}{c}\text { Difficulty to } \\
\text { pass stool }\end{array}$ & 3 & 2 & 1 & 0 \\
\hline
\end{tabular}

\section{Result}

As soon as the leech application was started, patient got relieved of pain and heaviness. Her agony and discomfort level was also reduced. After second sitting, size of prolapsed hemorrhoid was also reduced. Mass was also able to reduce in anal canal after proper lubrication with Jatyadi oil. After third sitting, she was completely relieved and satisfied with the treatment. So, she was discharged after giving proper diet instructions (Figure: 2, 3).

\section{Follow-up}

Patient was called for follow-up after 5 days in OPD. She was very happy and satisfied. On examination, it was observed that hemorrhoid mass was shrink in size. No bleeding or pain was observed during per-rectum examination.

\section{Discussion and conclusion}

In the past, leeches were used for a variety of applications as a medical tool. Their mechanism of action was not understood. All that counted was curing or relieving the problem. Today, scientific studies concerning the active substances in leeches have given us a better understanding of how they work and have given credit to their use. In traditional medicine, a lot of the old applications are still used, although our degree of understanding has evolved. Due to the qualities of its anticoagulant, vasodilator, thrombolytic, antiinflammatory and anaesthetizing substances, leeches has been proved as a medical device (9). Through their sucking effect, leeches stimulate circulation of cells at risk of necrosis and maintain oxygenation of the tissue. They therefore promote restoration of capillary anastomosis. They accelerate the hematoma decongestion process (10). They ensure drainage and, by partially or totally replacing venous return, they can be used in venous disorders. The benefit of leeches is that they are particularly attracted to deoxygenated blood.

In the present study, the successes story of leech therapy was pragmatic in an emergency condition of hemorrhoid. Leeches can be used to restore blood circulation in blocked veins by removing pooled blood. 


\section{References}

1. Kaviraja Ambika Datta Shastri, Sushruta Samhita Sutra Sthana 33/4, Part I, By Sushrutha with Ayurveda Tantvasandipika commentary, Varanasi, Choukhamba Sanskrit Sansthan, 2003, P-126.

2. Pandit Kashinath Shasrti, Charaka Samhita Sutra Sthana 11/49, By Charak with Vidyotani Hindi Commentary, Varanasi, Choukhamba Sanskrit Sansthan, 2007.

3. Kaviraja Ambika Datta Shastri, Sushruta Samhita Sutra Sthana 24/9, Part I, By Sushrutha with Ayurveda Tantvasandipika commentary, Varanasi, Choukhamba Sanskrit Sansthan, 2003, P-101.

4. Kaviraja Ambika Datta Shastri, Sushruta Samhita Sutra Sthana 33/10, Part I, By Sushrutha with Ayurveda Tantvasandipika commentary, Varanasi, Choukhamba Sanskrit Sansthan, 2003, P-127.

5. Kaviraja Ambika Datta Shastri, Sushruta Samhita Sutra Sthana 14/24, Part I, By Sushrutha with
Ayurveda Tantvasandipika commentary, Varanasi, Choukhamba Sanskrit Sansthan, 2003, P-53.

6. Kaviraja Ambika Datta Shastri, Sushruta Samhita Chikitsa Sthana 6/7, Part I, By Sushrutha with Ayurveda Tantvasandipika commentary, Varanasi, Choukhamba Sanskrit Sansthan, 2003, P-37.

7. Pandit Kashinath Shasrti, Charaka Samhita Chikitsa Sthana 14/61, By Charak with Vidyotani Hindi Commentary, Varanasi, Choukhamba Sanskrit Sansthan, 2007.

8. Dr. Brahmanand Tripathi, Ashtang Hridaya chikitsa Sthana, 8/28, By Vagbhatta, Varanasi, Choukhamba Sanskrit Sansthan, 2009.

9. Andreas Michalsen, Manfred Roth, Gustav Dobos; Medicinal Leech Therapy, New York 2007; P-132.

10. Elder A, Orevi M, Rigbi M. The role of leech in medical therapeutics. Blood Rev.1996; P-201.

Figure 1:

\section{Temperature Charting}

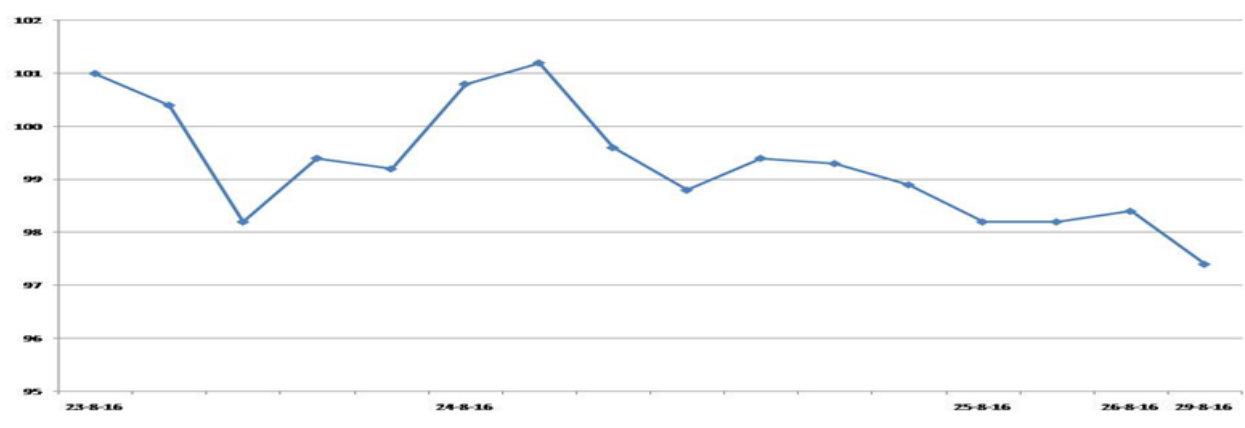

Figure 2:

Figure 3:
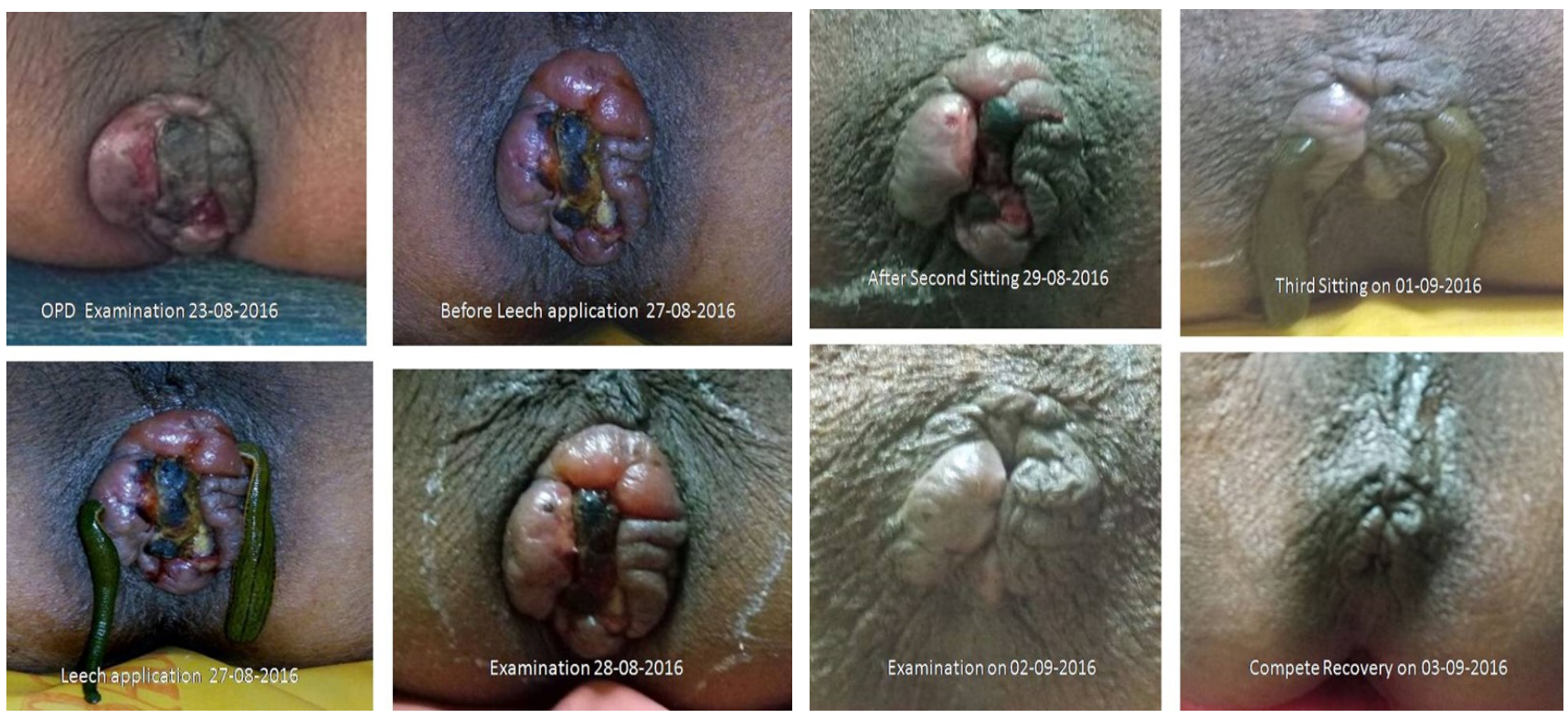

$* * * * *$ 